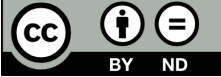

\section{Matkailututkimus-lehti uudistusten äärellä}

Outi Rantala, Lapin yliopisto, Matkailualan tutkimus- ja koulutusinstituutti (MTI) Heli Ilola, Lapin yliopisto, Matkailualan tutkimus- ja koulutusinstituutti (MTI)

Elämme parhaillaan hyvin erikoista aikaa. Esimerkiksi Lapin yliopisto, josta käsin Matkailututkimus-lehteä on viime vuodet toimitettu, on suljettuna koronavirusepidemian takia, ja toimitamme lehteä kotikonttoreissa. Lehden toimittamisen lisäksi moni muukin yhteiskunnallinen toiminta on siirtynyt julkisista tiloista koteihin. Tämä vaikuttaa tutkimuskohteisiimme eli matkailuun, virkistykseen ja vapaa-aikaan monin tavoin. Tilanne on herättänyt vilkasta keskustelua matkailututkijoiden piirissä niin Suomessa kuin kansainvälisesti.

Myös Matkailututkimus-lehti haluaa osallistua keskusteluun: Lehden toimituskunnan työstämä kirjoituskutsu tulevalle syksylle - otsikolla Slowing down with tourism - löytyy lehden kotisivulta. Kirjoittajakutsussa kysymme, mitä voimme oppia käsillä olevasta tilanteesta - miten voimme pysähtyä ja olla valmiita muutokseen? Kutsumme mukaan erityisesti vapaamuotoisia kirjoituksia, joissa käsitellään haavoittuvuuden, vastarinnan, toivon, resilienssin, palautumisen ja jälleenrakentamisen roolia matkailussa.

Toimituskunnan käymä vilkas keskustelu sekä halu viedä keskustelua eteenpäin lehden syysnumerossa on osoitus voimistuneesta talkoohengestä ja solidaarisuudesta (ks. myös Jenni Mäenpään pääkirjoitus Tieteen talkoolaiset Media $\&$ Viestintä -lehden tämän vuoden ensimmäisessä numerossa). Samalla se on osoitus siitä, että Matkailututkimus-lehden uudistamiseksi tehty työ alkaa tuottaa tulosta.

\section{Toteutettuja undistuksia}

Viimeisen vuoden aikana olemme uudistaneet lehteä useallakin tavalla. Lehden vanhat numerot löytyvät nyt journal.fi-palvelusta lehden sivuilta (Arkistot). Tämän vuoden alussa otimme käyttöön myös artikkeleiden ennakkojulkaisun: vertaisarvioidut artikkelit ja katsausartikkelit julkaistaan lehden sivuilla heti niiden valmistuttua (Tulevat artikkelit).

Olemme ottaneet käyttöön kaikissa lehdessä julkaistavissa kirjoituksissa DOI-tunnisteen eli elektronisten aineistojen pysyvän tunnisteen (Digital Object Identifier). Niin ikään olemme ottaneet käyttöön Creative Commons -lisenssin (Nimeä EiMuutoksia eli CC BY-ND 4.0), joka antaa lukijoille luvan jakaa lehdessä julkaistavia artikkeleita ja muita kirjoituksia mutta ei 
muokata niitä. Lisäksi lehtemme on juuri hyväksytty mukaan DOAJ-tietokantaan (Directory of Open Access Journals) eli kansainväliseen avointen tieteellisten lehtien rekisteriin. DOAJ:n kautta lehden julkaisujen metadata on vapaasti erilaisten tietokantojen, kirjastojen, julkaisijoiden sekä hakukoneiden käytössä - esimerkkejä näistä ovat Scopus, Serial Solutions ja Ebsco. Näin pääsy mukaan DOAJ-rekisteriin lisää lehden näkyvyyttä.

Olemme pyrkineet lisäämään lehden näkyvyyttä myös laajentamalla toimituskuntaa. Uusi kansainvälinen ja monitieteinen toimituskunta on sitoutunut auttamaan lehden sisällön tuotannossa ja lehden tunnettuuden lisäämisessä. Lisäksi lehdelle on nimetty viestinnästä vastaava toimituskunnan jäsen, yliopistonlehtori José-Carlos García-Rosell Lapin yliopistosta. Hän vastaa lehden viestintään liittyvistä asioista ja on perustanut lehdelle Twitter-tilin: @FJTR_ Journal.

\section{Kuinka tehdä lehdestä mahdollisimman käytettävä?}

Osa toteutetuista uudistuksista liittyy Suomen tiedekustantajien liiton järjestämään peruskurssiin, jolle päätoimittaja osallistui syksyn 2019 ja kevään 2020 aikana. Kurssi tarjosi runsain mitoin ajankohtaista tietoa muun muassa avoimesta julkaisemisesta ja suomalaisesta tiedeviestinnästä. Lisäksi se mahdollisti verkostoitumisen suomalaisten tiedelehtien toimittajien ja tiedekustantajien kanssa. Yhä useampaa suomalaista tiedelehteä julkaistaan Tieteellisten Seurain Valtuuskunnan (TSV) ylläpitämän journal.fi-alustan kautta. Tämä - samoin kuin se, mitä kaikkia mahdollisuuksia ja haasteita avoimeen julkaisemiseen liittyy - on konkretisoitunut tiedetoimittajien kanssa tapahtuneen verkostoitumisen myötä.

TSV pyrkii kannustamaan lehtiä avoimeen julkaisukulttuuriin tekemällä julkaisemisesta helppoa ja käytännöllistä. Voidaan ajatella, että kun tieteellinen tieto on saatavilla avoimesti ja omalla kielellä, se on myös helposti käytettävää. Käytettävyyttä voidaan kuitenkin tarkastella eri näkökulmista. Kenelle tieto on käytettävää? Palveleeko se erilaisia käyttäjiä? Entä palveleeko suomalaisessa tiedelehdessä julkaistu teksti sen kirjoittanutta tutkijaa itseään? Miten saavuttaa erilaiset lukijakunnat? Riittääkö, että lehtiin luodaan erilaisia osastoja, jotka mahdollistavat myös vapaamuotoisemman julkaisemisen? Miten rohkaista tutkijoita julkaisemaan tieteellistä tietoa uusilla tavoilla? Mustajoen (2013) mukaan tarvitaan oikein muotoiltuja sanoja ja tarkoin harkittuja kuvia, kun tietoa halutaan saattaa ihmisten ulottuville - ja lisäksi vielä rohkeutta, "todellisen elämän" tuntemusta, harjoittelua ja aikaa. Voidaan myös kysyä, tulisiko lehtien olla aktiivisesti esillä sosiaalisessa mediassa.

Näihin kysymyksiin olemme omalta osaltamme pyrkineet vastaamaan uudistamalla Matkailututkimus-lehden osastoja. Lehteen on otettu mukaan esimerkiksi Näkökulmia-osasto, jolla voi julkaista ajankohtaisia, muodoltaan ja tyyliltään vapaampia kirjoituksia (kuten Pasi Satokankaan kirjoitus tässä numerossa). Toisaalta pyrimme tuottamaan kirjoittajakutsuja, jotka reagoivat ajankohtaisiin aiheisiin - kuten nyt avoinna oleva kutsu, jossa haastamme tutkijat reflektoimaan ajankohtaista tilannetta esimerkiksi haastatteluiden, keskinäisen vuoropuhelun tai vaikkapa runon muodossa.

Monitieteisyys on yksi vastaus uusien ja moninaisten lukijakuntien tavoittamiseen. Olemme pyrkineet huomioimaan tätä toteuttamalla monitieteisiä teemanumeroita ja kutsumalla toimituskuntaan matkailuun ja vapaa-aikaan liittyviä asiantuntijoita hyvin laaja-alaisesti. 
Tieteelliselle julkaisemiselle asetetaan nykyisin kovia tulostavoitteita: tutkimustuloksia tulisi julkaista mahdollisimman hyviksi luokitelluissa tieteellisissä lehdissä ja vertaisarvioitujen artikkeleiden muodossa, jotta sekä tutkimusorganisaatio että tutkija voivat käyttää julkaisuja hyödyksi esimerkiksi rahoituksen hakemisessa tai työnhaussa ja meritoitumisessa. Koska suomalaiset tiedelehdet eivät yleensä sijoitu julkaisuluokitteluissa kovin korkealle, niissä - etenkään vertaisarvioimattomassa muodossa - julkaistu tieto ei ole tässä mielessä käytettävää. Toivomme, että lehden pääsy mukaan DOAJ-tietokantaan edistää lehden saavutettavuutta myös kansainvälisesti.

Julkaisemalla avoimesti tutkija saavuttaa erilaisia yleisöjä ja laajemman lukijakunnan. Avoimesti suomen kielellä - populaaristikin - julkaistun tiedon voidaan ajatella olevan käytettävää myös tutkijan näkökulmasta, jos hänen tavoitteenaan on luoda ymmärrystä, tuottaa ratkaisuja tai osallistua yhteiskunnalliseen keskusteluun. Toivommekin, että Matkailututkimus-lehti tarjoaa tulevaisuudessa foorumin monipuoliselle ja laadukkaalle matkailua, vapaa-aikaa ja virkistystä koskevalle keskustelulle.

\section{Monipuolinen ja monitieteinen numero}

Edellä todetun tavoitteen mukaisesti käsillä olevaa numeroa voi kutsua aidosti monipuoliseksi ja monitieteiseksi. Se koostuu eri tieteenaloilta tulevien tutkijoiden tutkimusartikkeleista sekä vapaamuotoisemmista kirjoituksista ja uutisista.

Numeron avaa Maria Lähteenmäen ja Alfred Colpaertin historiantutkimusta edustava tutkimusartikkeli. Siinä arvioidaan toisen maailmansodan jälkeen rakentunutta Petsamon muistipolitiikkaa ja todetaan Petsamon jääneen perifeeriseksi juonteeksi niin suomalaisessa sodanjälkeisessä muistipolitiikassa kuin nostalgiamatkailussa.

Kahdessa seuraavassa tutkimusartikkelissa käsitellään kalastusmatkailua. Kauppatieteitä edustavien matkailututkijoiden Lari Turusen, Raija Komppulan ja Jarno Sunin tutkimuksen kohteena ovat suomalaiset kalastuksen harrastajat. Tutkimuksessa tarkastellaan kalastusmatkailuelämyksen arvoa kulutusarvoteorian viitekehystä soveltaen; siinä huomioidaan myös yhteisöllisyyden keskeinen rooli kalastusmatkailussa. Lisäksi tunnistetaan eri kalastusmatkailijatyyppejä. Oikeustieteilijä Eelis Paukku puolestaan kysyy, miten nykyinen lainsäädäntö ja muu julkisen vallan asettama sääntely vaikuttavat kalastuksen eri muotoihin, miten kalastuksen eri muodot tuottavat taloudellista arvoa ja miten sääntelyä kehittämällä voitaisiin parantaa kalastusmatkailun edellytyksiä Suomessa. Yhtenä tutkimuksensa johtopäätöksenä Paukku toteaa, että kalastusmatkailu tuottaa huomattavasti enemmän arvoa kalastettua kalaa kohden kuin muut kalastuksen muodot. Lisäksi kalastusmatkailun tuottama arvo jää selkeämmin alueelle, kun taas kaupallisen kalastuksen arvo jakautuu jalostukseen ja vähittäismyyntiin. Nämä kaksi artikkelia tarjoavat yhdessä arvokasta tietoa kalastusmatkailun kehittämiseen Suomessa.

Numeron neljännessä tutkimusartikkelissa Suomen ympäristökeskuksen tutkijat Anna Strandell, Kati Pitkänen ja Antti Rehunen arvioivat, miten mökeillä vietetty aika kehittyy Suomessa määrällisesti vuoteen 2040 mennessä ja miten väestön ikääntyminen ja kaupungistuminen vaikuttavat muutokseen. Tutkimuksensa perusteella Strandell, Pitkänen ja Rehunen ku- 
moavat väitteen, jonka mukaan mökkeily olisi Suomessa hiipuva vapaa-ajanviettotapa. Heidän mukaansa vapaa-ajan asuminen säilynee tulevaisuudessakin keskeisenä maaseudun ja kaupungin välisen vuorovaikutuksen muotona.

Ritva Saari, Emily Höckert, Monika Lüthje, Outi Kugapi ja Nuccio Mazzullo tarttuvat katsausartikkelissaan ongelmiin, jotka liittyvät saamelaiskulttuurin esittämiseen Suomen matkailuelinkeinon piirissä. Artikkelissa nostetaan esille kulttuurisen herkistymisen käsite yhtenä mahdollisuutena vaihtoehtoisten ratkaisumallien löytämiseksi sekä avuksi ongelmakohtien ratkaisuun.

Käsillä olevan numeron ensimmäisessä puheenvuorossa Pasi Satokangas pohtii matkailun talousvaikutusselvitysten menetelmiä käyttäen esimerkkinä Tunturi-Lapin tilannetta. Jonna Kielenniva puolestaan tarkastelee ihmisen, teknologian ja lain rooleja lentokentän turvallisuuden rakentumisessa. Francesc Fusté-Forné tuo omassa puheenvuorossaan esiin maatalouden ja matkailun kytköksiä ruokamatkailun näkökulmasta.

Luontomatkailun teemaa edustaa Miisa Pietilän lektio kokemuksellisen paikkatiedon hyödyntämisestä luonnon virkistyskäytön suunnittelussa. Vuonna 2018 valmistuneen, Oulangan kansallispuistoon kohdistuneen väitöstutkimuksen lähtökohtana oli koettu tarve saada kävijät mukaan kansallispuistojen suunnitteluun. Tutkimus toi esiin niitä käytännön haasteita, joiden kanssa puistojen työntekijät päivittäin kamppailevat sekä tarjosi välineitä näistä haasteista selviämiseen.

Numeron päättää Pasi Satokankaan ajankohtainen Näkökulma-kirjoitus lähimatkailusta. Kirjoitus herättelee lukijaa pohtimaan, mitä hyötyä lähimatkailusta voi olla. Kirjoitus osoittaa samalla jo suuntaa kohti lehden seuraavaa numeroa, jossa toivomme keskustelun jatkuvan käsillä olevan virusepidemian vaikutuksista.

Aivan lehden lopuksi kerromme vielä professori Jarkko Saariselle myönnetystä AAG:n John Rooney -palkinnosta ja onnittelemme häntä lämpimästi palkinnon johdosta! Erilaisia uutisia ja muita ajankohtaisia tiedotteita otetaan lehteen mielellään vastaan jatkossakin.

Tämä on viimeinen Matkailututkimus-lehden numero, jonka olemme toimittaneet yhteistuumin Lapin yliopistosta käsin. Kiitämme Lapin yliopistoa työajasta, jonka puitteissa se on mahdollistanut lehden uudistamisen ja toimittamisen. Jatkossa toimitussihteerin tehtävistä vastaa Suomen matkailututkimuksen seura.

Rovaniemellä huhtikuussa 2020,

Outi Rantala ja Heli Ilola

\section{Lähteet}

Mustajoki, A. (2013). Johdanto. Teoksessa U. Strellman \& J. Vaattovaara (toim.), Tieteen yleistajuistaminen (s. 15-20). Gaudeamus.

Mäenpää, J. (2020). Tieteen talkoolaiset. Media \&Viestintä, 43(1), i-iii. 43(1). https://journal.fi/mediaviestinta/article/view/91077 